\title{
Needs Assessment of Biology Learning Materials for Integration Curriculum in Chandra Kumala School
}

\author{
Kurikulum 2013 (K13) and Cambridge International Examination (CIE)
}

\author{
Silvia Sabatini \\ SMPN 7 Percut Sei Tuan \\ Dinas Pendidikan Kabupaten \\ Deliserdang \\ Medan, Indonesia \\ zinniaelegans.silvia@gmail.com
}

\author{
Binari Manurung \\ Biology Department \\ Postgraduate Program of Universitas \\ Negeri Medan \\ Medan, Indonesia \\ binarimanurung@unimed.ac.id
}

\author{
Mufti Sudibyo \\ Biology Department \\ Postgraduate Program of Universitas \\ Negeri Medan \\ Medan, Indonesia \\ muftisudibyo@unimed.ac.id
}

\begin{abstract}
The impact of globalization is multidimensional; the impact is also felt in the field of education, especially higher education that directly interacts with the international community. Specifically, globalization is driving the changing role of higher education institutions. Higher education institutions are challenged to change the curriculum in total. The integration curriculum is a blend of the current national curriculum in Indonesia (Kurikulum 2013) and foreign curriculum (some schools usually use CIE as awarding bodies from England). So far, the implementation of integration curriculum in national plus schools has been going well and has a positive impact for all parties, but it also has many shortcomings. The main problem is the unavailability of appropriate learning material for both of the curriculums. The research has the aim to investigate the learning needs of teachers and students by needs assessment. The research aspects were investigated and evaluated through a needs analysis conducted by doing interview, administering questionnaire and analyzing documents.
\end{abstract}

Keywords: integration curriculum; learning materials; biology; needs assessment

\section{INTRODUCTION}

The impact of globalization is multidimensional; the impact is also felt in the field of education, especially higher education that directly interacts with the international community. Specifically, globalization is driving the changing role of higher education institutions. Role as a traditional learning institution cannot be maintained and needs to be transformed into a knowledge-creating institution. In the meantime, randomly generated planning must be converted into strategic planning. From the point of view of the challenge, the comparative approach should be transformed into a competitive approach.

Higher education institutions are challenged to change the curriculum in total. Curriculum emphasis is no longer on content or knowledge but on the development of learning, creative skills, and the use of new information and communication technologies. One form of curriculum development that has recently received serious attention is the integration curriculum. It is true that an integrated curriculum is an integral part of instructional innovation that invites students to study and discuss contextually, studying naturally available phenomena.

According to Government Regulation No. 31 of 2014 Article 1 verse 6, that the Cooperation Education Unit referred to as SPK (Satuan Pendidikan Kerjasama) is an educational unit organized or managed on the basic of cooperation between Foreign Education Institution accredited / recognized in the country and the Indonesian Education Institution on the formal or informal path in accordance with the provisions of legislation. (Peraturan Kemdikbud.2014)

Based on the research by Purnomo (2015), integration curriculum is a curriculum development to facilitate teachers in organizing the learning process. Integration curriculum should be done by a school that applies more than one curriculum. So that learners also have no difficulty in understanding the material given and able to achieve the main competencies in each curriculum very well. To support it, creativity of teachers is needed in organizing this integrated curriculum in the classroom. The support from principals and vice principals is also needed for the preparation and implementation of the integration curriculum.

The integration curriculum is a blend of the current national curriculum in Indonesia (Kurikulum 2013) and foreign curriculum (some schools usually use CIE as awarding bodies from England). The integrated curriculum is more concerned that in a subject must be integrated thoroughly. This integration can be achieved through focusing lessons on a particular problem with alternative solutions through the various disciplines or subjects required so that the boundaries between subjects can be eliminated. The existence of the learning process is not focused on studying the subjects, but the subjects are only used as a means to approach the problems that are the focus of the study. This enables each learner to acquire a learning experience appropriate to his or her own interests and talents, and can psychologically be a means of personal development intact. The subjects, however, are subjected to by the educator when the subject takes place as a guide and center for the integration of the topic, so that the learning and teaching 
spirit does not leave the subjects set by the government to meet national education objectives.

So far, the implementation of integration curriculum in national plus schools has been going well and has a positive impact for all parties. But this integration curriculum also has many shortcomings. Then the unavailability of teaching materials is adequate for both curriculums simultaneously to be held. So for the initial research phase before developing a teaching material product, it is necessary to do a need assessment first.

\section{MATERIALS AND METHODS}

\section{A. Research Design}

This study employs descriptive and qualitative design as it reveals some aspects of integrated curriculum learning material. They are: effectiveness, display, language used and content. Those aspects were investigated and evaluated through a needs analysis conducted by doing interview, administering questionnaire and analyzing documents. The procedures were employed as the methods of data collection. The result of the needs analysis, hopefully, could become the inputs for future development of the learning material.

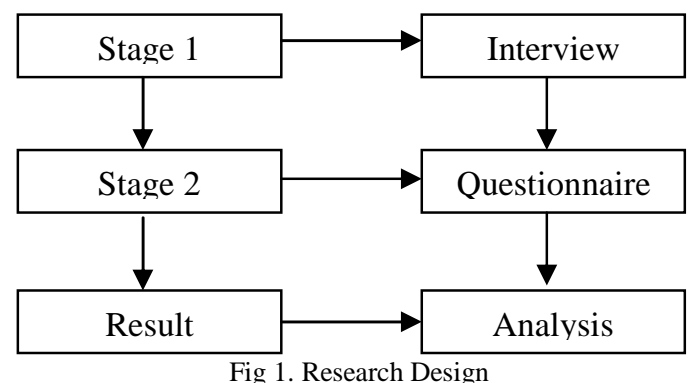

1) Respondents: The respondents in this research were all secondary teachers (40 person) and all IGCSE $2 / 4^{\text {th }}$ grade of secondary students ( 80 person) of Chandra Kumala School (Cambridge School ID 124) totalling 130 people.

2) Instruments: The needs assessment research data was collected by using interview questions and questionnaire questions. The primary data was collected in the form of qualitative, by the form of interview result from the respondents. There are 23 interview questions for students and 12 interview questions for teachers. The secondary data that was collected in this research is belonging to the descriptive quantitative data. It was collected by the following categories (modified from Likert scale): (1) bad / not feasible, (2) not good / less feasible, (3) good / feasible, (4) excellent / very feasible. There are 16 questionnaire questions for teachers. The questions grid was related with some aspects, namely:
a) National curriculum textbook (Erlangga) and CIE textbook (Cambridge University Press)
b) Suitability of teaching materials
c) Teacher mastery
d) Teaching method
e) Learning experience

f) Indicators demanded in the scientific literacy skills, including: science as body of knowledge, science as a way of thinking, science as a way of investigating also an interaction of science, technology and society.

\section{RESULTS AND DISCUSSION}

A. Results

1) Interview results

a) Interview with teachers: Based on interviews conducted with the teachers, the results are as follows:

TABLE I. THE INTERVIEW RESULTS WITH TEACHERS

\begin{tabular}{|c|c|c|}
\hline No & Questions & General Answer \\
\hline 1 & $\begin{array}{l}\text { Do you understand the } \\
\text { level of educational units } \\
\text { in the National Curriculum } \\
\text { (Curriculum 2013) and } \\
\text { Cambridge International } \\
\text { Examination (CIE)? }\end{array}$ & $\begin{array}{l}\text { In general, understand } \\
\text { because I have } \\
\text { participated in several } \\
\text { training sessions. }\end{array}$ \\
\hline 2 & $\begin{array}{l}\text { Which learning material } \\
\text { that is felt to be in } \\
\text { accordance with the } \\
\text { development of science? } \\
\text { K13 or CIE? }\end{array}$ & $\begin{array}{l}\text { Both are sufficient in } \\
\text { accordance with the } \\
\text { development of } \\
\text { science. }\end{array}$ \\
\hline 3 & $\begin{array}{l}\text { Which of the National } \\
\text { Curriculum teaching } \\
\text { materials (Kurikulum } \\
\text { 2013) or Cambridge } \\
\text { International Examination } \\
\text { (CIE) reference teaching } \\
\text { materials that are felt to } \\
\text { encourage students to } \\
\text { think critically? }\end{array}$ & $\begin{array}{l}\text { Both of them can } \\
\text { encourage students to } \\
\text { think critically, but it } \\
\text { must be admitted that } \\
\text { books published by } \\
\text { Cambridge University } \\
\text { Press are more real in } \\
\text { providing examples. }\end{array}$ \\
\hline 4 & $\begin{array}{l}\text { Which of the National } \\
\text { Curriculum teaching } \\
\text { materials (Kurikulum } \\
\text { 2013) or the Cambridge } \\
\text { International Examination } \\
\text { (CIE) reference teaching } \\
\text { material that is felt to } \\
\text { encourage student } \\
\text { motivation? }\end{array}$ & $\begin{array}{l}\text { Both of them can } \\
\text { encourage student } \\
\text { learning motivation, } \\
\text { because motivation } \\
\text { actually comes from } \\
\text { yourself. }\end{array}$ \\
\hline 5 & $\begin{array}{l}\text { Which of the National } \\
\text { Curriculum teaching } \\
\text { materials (Kurikulum } \\
\text { 2013) or the Cambridge } \\
\text { International Examination } \\
\text { (CIE) reference teaching } \\
\text { material that is felt to } \\
\text { increase scientific literacy } \\
\text { skills in students? }\end{array}$ & $\begin{array}{l}\text { For scientific literacy, } \\
\text { the questions given to } \\
\text { national teaching } \\
\text { materials are far } \\
\text { behind. For CIE they } \\
\text { have } 6 \text { papers in the } \\
\text { exam which contain } \\
\text { different competencies. } \\
\text { Of course the problem } \\
\text { is very different from } \\
\text { what we usually use }\end{array}$ \\
\hline
\end{tabular}




\begin{tabular}{|c|c|c|}
\hline & & here. \\
\hline 6 & $\begin{array}{l}\text { Does the material in the } \\
\text { National Curriculum } \\
\text { teaching materials } \\
\text { (Kurikulum 2013) can } \\
\text { cover all indicators } \\
\text { demanded in the } \\
\text { Cambridge International } \\
\text { Examination (CIE) } \\
\text { reference curriculum? }\end{array}$ & $\begin{array}{l}\text { Not yet, because the } \\
\text { material in the national } \\
\text { curriculum }(K 13) \text { is } \\
\text { still too general and } \\
\text { lacks specific demands } \\
\text { in each KI, KD and } \\
\text { indicators. }\end{array}$ \\
\hline 7 & $\begin{array}{l}\text { Does the material in the } \\
\text { Cambridge International } \\
\text { Examination (CIE) } \\
\text { reference curriculum can } \\
\text { cover all indicators } \\
\text { demanded in the National } \\
\text { Curriculum teaching } \\
\text { materials (Kurikulum } \\
\text { 2013)? }\end{array}$ & $\begin{array}{l}\text { Most of them already, } \\
\text { almost } 80 \% \text { of the } \\
\text { material in the national } \\
\text { curriculum can be } \\
\text { covered by CIE. }\end{array}$ \\
\hline 8 & $\begin{array}{l}\text { Are you able to teach } \\
\text { integration learning } \\
\text { material using the National } \\
\text { Curriculum teaching } \\
\text { material (Kurikulum 2013) } \\
\text { only? }\end{array}$ & $\begin{array}{l}\text { Not able to because it } \\
\text { is very inadequate. }\end{array}$ \\
\hline 9 & $\begin{array}{l}\text { Are you able to teach } \\
\text { integration learning } \\
\text { material using only } \\
\text { Cambridge International } \\
\text { Examination (CIE) } \\
\text { reference material? }\end{array}$ & $\begin{array}{l}\text { Not able to because } \\
\text { there are demands in } \\
\text { K13 that are not found } \\
\text { in CIE. }\end{array}$ \\
\hline 10 & $\begin{array}{l}\text { Do you find it difficult to } \\
\text { teach integration using } \\
\text { separate teaching materials } \\
\text { between the National } \\
\text { Curriculum (Kurikulum } \\
\text { 2013) and Cambridge } \\
\text { International Examination } \\
\text { (CIE)? }\end{array}$ & $\begin{array}{l}\text { Yes, that is the } \\
\text { difficulty experienced } \\
\text { since the establishment } \\
\text { of the SPK (Satuan } \\
\text { Pendidikan } \\
\text { Kerjasama). The } \\
\text { absence of integrated } \\
\text { teaching materials to } \\
\text { teach the integration } \\
\text { curriculum. }\end{array}$ \\
\hline 11 & $\begin{array}{l}\text { Do you need teaching } \\
\text { materials that integrate the } \\
\text { National Curriculum } \\
\text { (Kurikulum 2013) and } \\
\text { Cambridge International } \\
\text { Examination (CIE)? }\end{array}$ & $\begin{array}{l}\text { It is very important that } \\
\text { the teacher and } \\
\text { students are no longer } \\
\text { confused in matching } \\
\text { the material. There are } \\
\text { times when learning } \\
\text { with CIE then } K 13 \text {, this } \\
\text { makes students feel as } \\
\text { if there is a very big } \\
\text { difference between the } \\
\text { two, even though } \\
\text { equations can still be }\end{array}$ \\
\hline
\end{tabular}

\begin{tabular}{|l|l|l|}
\hline 12 & $\begin{array}{l}\text { If you review the existing } \\
\text { textbooks or teaching } \\
\text { materials, do you meet the } \\
\text { following 4 components: } \\
\text { 1) science as a body of } \\
\text { knowledge (presenting } \\
\text { facts, concepts and laws); } \\
\begin{array}{l}\text { 2) science as a way to } \\
\text { investigate; 3) science as } \\
\text { a way of thinking } \\
\text { (emphasizing the } \\
\text { empirical nature and } \\
\text { objectivity of science), 4) } \\
\text { interaction between } \\
\text { technology science and } \\
\text { society. }\end{array}\end{array}$ & $\begin{array}{l}\text { It is unfortunate that } \\
\text { the national curriculum } \\
\text { teaching materials are } \\
\text { good but still need a lot } \\
\text { of improvement here } \\
\text { and there. There is } \\
\text { nothing wrong with us } \\
\text { adopting teaching } \\
\text { materials from others. }\end{array}$ \\
\hline
\end{tabular}

b) Interview with students: Based on interviews conducted with the teachers, the results are as follows:

TABLE II. THE INTERVIEW RESULTS WITH STUDENTS

\begin{tabular}{|c|c|c|}
\hline No & Questions & General Answer \\
\hline 1 & $\begin{array}{l}\text { In your opinion, what } \\
\text { biology materials do you } \\
\text { find difficult to } \\
\text { understand? }\end{array}$ & $\begin{array}{l}\text { Taxonomy and } \\
\text { ecology, because there } \\
\text { are too many terms and } \\
\text { too abstract. Too much } \\
\text { is memorized, } \\
\text { especially when it } \\
\text { comes to cycles. } \\
\text { Ecology is also divided } \\
\text { into one new course in } \\
\text { Environmental } \\
\text { Management. }\end{array}$ \\
\hline 2 & $\begin{array}{l}\text { What textbook do you use } \\
\text { / provided by the school to } \\
\text { help you study the topic? }\end{array}$ & $\begin{array}{l}\text { The books used at the } \\
\text { school are Erlangga for } \\
\text { national and } \\
\text { Cambridge University } \\
\text { Press (CUP) for } \\
\text { international. }\end{array}$ \\
\hline 3 & $\begin{array}{l}\text { What is the appearance } \\
\text { and presentation in the } \\
\text { textbook, do you think it is } \\
\text { interesting? Does the text } \\
\text { book motivate you in } \\
\text { learning? }\end{array}$ & $\begin{array}{l}\text { The division of sub } \\
\text { topics is slightly } \\
\text { different in Erlangga } \\
\text { and CUP. The book is } \\
\text { quite interesting and } \\
\text { motivating in learning. }\end{array}$ \\
\hline 4 & $\begin{array}{l}\text { What about the language } \\
\text { used in the textbook, do } \\
\text { you think it is clear and } \\
\text { easy to understand or is } \\
\text { still unclear and difficult } \\
\text { to understand? }\end{array}$ & $\begin{array}{l}\text { The language used is } \\
\text { quite good and easy to } \\
\text { understand. }\end{array}$ \\
\hline
\end{tabular}




\begin{tabular}{|c|c|c|}
\hline 5 & $\begin{array}{l}\text { Do the sample images and } \\
\text { cases contained in the } \\
\text { textbook match to the } \\
\text { material explained by the } \\
\text { teacher? }\end{array}$ & $\begin{array}{l}\text { The sample images } \\
\text { given in CUP are } \\
\text { clearer and not wordy } \\
\text { and are in accordance } \\
\text { with CIE exam } \\
\text { questions. If the } \\
\text { material in a national } \\
\text { book can sometimes be } \\
\text { different from the exam } \\
\text { material. }\end{array}$ \\
\hline 6 & $\begin{array}{l}\text { Are textbooks used using } \\
\text { illustrations that are close } \\
\text { to everyday life? }\end{array}$ & $\begin{array}{l}\text { For CIE material, the } \\
\text { examples given are } \\
\text { more global, but for } \\
\text { national material, } \\
\text { examples given } \\
\text { sometimes involve life } \\
\text { in Indonesia. }\end{array}$ \\
\hline 7 & $\begin{array}{l}\text { Does the text book give } \\
\text { you the opportunity to } \\
\text { study independently? }\end{array}$ & $\begin{array}{l}\text { Yes, in both books } \\
\text { there are practice } \\
\text { questions and } \\
\text { practicum guides. }\end{array}$ \\
\hline 8 & $\begin{array}{l}\text { Does the text book give } \\
\text { you the opportunity to } \\
\text { investigate the latest cases } \\
\text { in the fields of science, } \\
\text { technology and society? }\end{array}$ & $\begin{array}{l}\text { Not for all. This is } \\
\text { more commonly found } \\
\text { in CUP books. }\end{array}$ \\
\hline 9 & $\begin{array}{l}\text { Does the book make it } \\
\text { easy for you to learn with } \\
\text { an integrated curriculum? }\end{array}$ & $\begin{array}{l}\text { Not. It is precisely with } \\
\text { the existence of } 2 \\
\text { books and } 2 \\
\text { curriculums such as } \\
\text { there is no unity } \\
\text { obtained. It's as if all } \\
\text { are going on their own. }\end{array}$ \\
\hline 10 & $\begin{array}{l}\text { Are there any difficulties } \\
\text { you feel when learning an } \\
\text { integrated curriculum with } \\
\text { domestic publications? }\end{array}$ & $\begin{array}{l}\text { It is very difficult, } \\
\text { because the domestic } \\
\text { books are still } \\
\text { incomplete. There are a } \\
\text { lot of demands on CIE. }\end{array}$ \\
\hline 11 & $\begin{array}{l}\text { Are there any difficulties } \\
\text { you feel when learning an } \\
\text { integrated curriculum with } \\
\text { books published abroad? }\end{array}$ & $\begin{array}{l}\text { For national material, } \\
\text { the } 80 \% \text { has been } \\
\text { covered in CIE. }\end{array}$ \\
\hline 12 & $\begin{array}{l}\text { Do you use other books as } \\
\text { learning resources other } \\
\text { than textbooks? }\end{array}$ & None. \\
\hline 13 & $\begin{array}{l}\text { If so, where did the book } \\
\text { come from? Is the book } \\
\text { made by the teacher or by } \\
\text { the publisher? If it is from } \\
\text { a publisher, write the name } \\
\text { of the publisher. }\end{array}$ & None. \\
\hline 14 & What about the language & It's good and easy to \\
\hline
\end{tabular}

\begin{tabular}{|c|c|c|}
\hline & $\begin{array}{l}\text { used in the teaching } \\
\text { material, do you think it is } \\
\text { easy to understand or } \\
\text { difficult to understand? }\end{array}$ & understand. \\
\hline 15 & $\begin{array}{l}\text { Does the book / teaching } \\
\text { material help you to } \\
\text { understand material } \\
\text { concepts that are poorly } \\
\text { understood or otherwise } \\
\text { make you more confused? }\end{array}$ & $\begin{array}{l}\text { CIE material book is } \\
\text { clearer than national } \\
\text { book. }\end{array}$ \\
\hline 16 & $\begin{array}{l}\text { Does the book you use } \\
\text { reveal what happened } \\
\text { around the life observed? }\end{array}$ & $\begin{array}{l}\text { CIE material book is } \\
\text { clearer than national } \\
\text { book. }\end{array}$ \\
\hline 17 & $\begin{array}{l}\text { In your opinion, should } \\
\text { biology teachers have an } \\
\text { educational background } \\
\text { that is in accordance with } \\
\text { what is taught? }\end{array}$ & $\begin{array}{l}\text { I think it should be. If } \\
\text { different, there will be } \\
\text { a deviation later }\end{array}$ \\
\hline 18 & $\begin{array}{l}\text { Have the teachers in the } \\
\text { class mastered any } \\
\text { material that will be } \\
\text { taught? Give your reasons. }\end{array}$ & $\begin{array}{l}\text { Already, because it's } \\
\text { quite clear in carrying } \\
\text { the subject matter. }\end{array}$ \\
\hline 19 & $\begin{array}{l}\text { Is there any } \\
\text { communication or } \\
\text { feedback between the } \\
\text { teacher and students in the } \\
\text { biology learning process in } \\
\text { the classroom? }\end{array}$ & $\begin{array}{l}\text { Yes it is. Teachers and } \\
\text { students often discuss } \\
\text { in class and students } \\
\text { ask material that is not } \\
\text { yet understood. }\end{array}$ \\
\hline 20 & $\begin{array}{l}\text { How is biology taught in } \\
\text { class by your teacher? } \\
\text { Does it use props or other } \\
\text { learning media? Can it } \\
\text { attract your attention while } \\
\text { studying? }\end{array}$ & $\begin{array}{l}\text { The method used is } \\
\text { quite varied, such as } \\
\text { explaining directly, } \\
\text { quizzes, experiments } \\
\text { and so on. }\end{array}$ \\
\hline 21 & $\begin{array}{l}\text { Do you have friends at } \\
\text { home or at school? Give } \\
\text { your explanation. }\end{array}$ & $\begin{array}{l}\text { There are group friends } \\
\text { and classmates who } \\
\text { sometimes come to the } \\
\text { house. Or just discuss it } \\
\text { at school. }\end{array}$ \\
\hline 22 & $\begin{array}{l}\text { Are there any different } \\
\text { concepts on the material } \\
\text { you learned in } K 13 \text { and } \\
\text { CIE? Give your reasons: }\end{array}$ & $\begin{array}{l}\text { During this time we felt } \\
\text { that it was two different } \\
\text { things, because the } \\
\text { implementation also } \\
\text { could not be in line. } \\
\text { After finishing one } \\
\text { national topic, then } \\
\text { next week discuss the } \\
\text { topic of CIE. }\end{array}$ \\
\hline 23 & $\begin{array}{l}\text { Do you need teaching } \\
\text { materials that integrate the } \\
\text { National Curriculum } \\
\text { (Kurikulum 2013) with }\end{array}$ & $\begin{array}{l}\text { I do, as a student, was } \\
\text { very much in need } \\
\text { because I was confused } \\
\text { with the two }\end{array}$ \\
\hline
\end{tabular}




\begin{tabular}{|l|l|}
\hline $\begin{array}{l}\text { Cambridge International } \\
\text { Examination (CIE)? }\end{array}$ & $\begin{array}{l}\text { curriculum and two } \\
\text { teaching materials that } \\
\text { did not intersect at all. }\end{array}$ \\
\hline
\end{tabular}

B. Questionnaire results

TABLE III. THE QUESTIONNAIRE RESULTS WITH TEACHERS

\begin{tabular}{|c|c|c|c|c|c|}
\hline \multirow{2}{*}{ No } & \multirow{2}{*}{ Questions } & \multicolumn{4}{|c|}{ Answer (\%) } \\
\hline & & 1 & 2 & 3 & 4 \\
\hline 1 & $\begin{array}{l}\text { I understand the level and } \\
\text { educational units in the } \\
\text { National Curriculum } \\
\text { (Kurikulum 2013). }\end{array}$ & - & - & 5 & 95 \\
\hline 2 & $\begin{array}{l}\text { I understand the of } \\
\text { educational units in the } \\
\text { curriculum referred to by } \\
\text { Cambridge International } \\
\text { Examination (CIE). }\end{array}$ & - & - & 10 & 90 \\
\hline 3 & $\begin{array}{l}\text { The material in the } \\
\text { National Curriculum } \\
\text { (Kurikulum 2013) } \\
\text { reference material is very } \\
\text { in line with the } \\
\text { development of science. }\end{array}$ & 5 & 15 & 75 & 5 \\
\hline 4 & $\begin{array}{l}\text { The material in the } \\
\text { Cambridge International } \\
\text { Examination (CIE) } \\
\text { reference material is very } \\
\text { in line with the } \\
\text { development of science. }\end{array}$ & - & 5 & 85 & 10 \\
\hline 5 & $\begin{array}{l}\text { The material in the } \\
\text { National Curriculum } \\
\text { (Kurikulum 2013) can } \\
\text { encourage students to } \\
\text { think critically. }\end{array}$ & 5 & 25 & 65 & 5 \\
\hline 6 & $\begin{array}{l}\text { The material in the } \\
\text { Cambridge International } \\
\text { Examination (CIE) can } \\
\text { encourage students to } \\
\text { think critically. }\end{array}$ & - & - & 20 & 80 \\
\hline 7 & $\begin{array}{l}\text { The material in the } \\
\text { National Curriculum } \\
\text { (Kurikulum 2013) can } \\
\text { encourage students' } \\
\text { learning motivation. }\end{array}$ & 20 & 50 & 30 & - \\
\hline 8 & $\begin{array}{l}\text { The material in the } \\
\text { Cambridge International } \\
\text { Examination (CIE) can } \\
\text { encourage students' } \\
\text { learning motivation. }\end{array}$ & - & 5 & 25 & 70 \\
\hline
\end{tabular}

\begin{tabular}{|c|c|c|c|c|c|}
\hline 9 & $\begin{array}{l}\text { The material in the } \\
\text { National Curriculum } \\
\text { (Kurikulum 2013) can } \\
\text { provoke science literacy } \\
\text { skills to students. }\end{array}$ & 5 & 30 & 60 & 5 \\
\hline 10 & $\begin{array}{l}\text { The material in the } \\
\text { Cambridge International } \\
\text { Examination (CIE) can } \\
\text { provoke science literacy } \\
\text { skills to students. }\end{array}$ & - & - & 10 & 90 \\
\hline 11 & $\begin{array}{l}\text { The material in the } \\
\text { National Curriculum } \\
\text { (Kurikulum 2013) } \\
\text { teaching materials } \\
\text { includes all indicators } \\
\text { demanded in the } \\
\text { Cambridge International } \\
\text { Examination (CIE). }\end{array}$ & 5 & 70 & 20 & 5 \\
\hline 12 & $\begin{array}{l}\text { The material in the } \\
\text { Cambridge International } \\
\text { Examination (CIE) } \\
\text { teaching materials } \\
\text { includes all indicators } \\
\text { demanded in the National } \\
\text { Curriculum (Kurikulum } \\
\text { 2013). }\end{array}$ & - & - & 10 & 90 \\
\hline 13 & $\begin{array}{l}\text { I was able to teach the } \\
\text { integration study material } \\
\text { by using only National } \\
\text { Curriculum (Kurikulum } \\
\text { 2013) teaching materials. }\end{array}$ & 10 & 80 & 10 & - \\
\hline 14 & $\begin{array}{l}\text { I was able to teach the } \\
\text { integration study material } \\
\text { by using only Cambridge } \\
\text { International Examination } \\
\text { (CIE) reference materials. }\end{array}$ & - & 5 & 30 & 65 \\
\hline 15 & $\begin{array}{l}\text { I find it difficult to teach } \\
\text { integration using separate } \\
\text { teaching materials } \\
\text { between the National } \\
\text { Curriculum (Kurikulum } \\
\text { 2013) and Cambridge } \\
\text { International Examination } \\
\text { (CIE). }\end{array}$ & - & - & 20 & 80 \\
\hline 16 & $\begin{array}{l}\text { I need teaching materials } \\
\text { that integrate between the } \\
\text { National Curriculum } \\
\text { (Kurikulum 2013) and } \\
\text { Cambridge International } \\
\text { Examination (CIE). }\end{array}$ & - & - & 5 & 95 \\
\hline
\end{tabular}




\section{Discussion}

1) Interview result discussion: From the results above, some data can be interpreted. Both of the curriculum can encourage students to think critically and encourage the motivation. But for the scientific literacy, they assume that CIE contains 6 papers in the test which contain various competencies. So that this form of evaluation can improve students' scientific literacy skill.

The result also show that the material in the National Curriculum teaching materials (Kurikulum 2013) can not cover all indicators demanded in the Cambridge International Examination (CIE) curriculum, but almost $80 \%$ of the material in the national curriculum can be covered by CIE.

They also find any difficulties to teach integration using separate teaching materials between the National Curriculum (Kurikulum 2013) and Cambridge International Examination (CIE). The students were very much in need the new learning material because they were confused with the two curriculum and two teaching materials that did not intersect at all.

2) Questionnaire result discussion: From the results above, some data can be interpreted in the percentage format, based on the answer from the respondents. More than $90 \%$ teachers understand the level and educational units in the National Curriculum (Kurikulum 2013). The 75\% thought that the material in the Cambridge International Examination (CIE) reference material is very in line with the development of science. More than $50 \%$ stated that material in the Cambridge International Examination (CIE) can encourage students to think critically.

There are around $70 \%$ who choose very agree and declare that the material in the Cambridge International Examination (CIE) can encourage students' learning motivation. Almost 90\% people very agree that the material in the Cambridge International Examination (CIE) can provoke science literacy skills to students.

In the opposite site, they was not able to teach the integration study material by using only National Curriculum (Kurikulum 2013) teaching materials and by using separate teaching materials. So any $95 \%$ declare that they need teaching materials that integrate between the National Curriculum (Kurikulum 2013) and Cambridge International Examination (CIE).

\section{CONCLUSION}

The results of this study indicate that almost all the respondent assume that:
- CIE material can improve students' scientific literacy skill,

- almost $80 \%$ of the material in the national curriculum can be covered by CIE,

- CIE can encourage students to think critically,

- the material in CIE can provoke science literacy skills to students,

- they need teaching materials that integrate between the National Curriculum (Kurikulum 2013) and CIE.

\section{ACKNOWLEDGMENT}

The author expresses the great gratitude to the supervisors: Prof. Dr. rer. nat. Binari manurung, M.Si. and Dr. Mufti Sudibyo, M.Si. who have provided constructive guidance and advice during this research. The author also thanked Chandra Kumala School and Rita, S.T., M.B.A., M.Pd. as the principal for allowing researchers to conduct the research at the school.

\section{REFERENCES}

[1] A. Puji. "A Needs Analysis in Developing a Writing Curriculum for EFL Education Students: A Case Study at the Department of English Education of Semarang State University," Journal of Language and Literature, Indonesia, vol. IV, pp. 30-40, October 2009.

[2] D. Wahyuningsih, Suyanto and A. Ghufron. "Needs Assessment of Blended Learning Management in Higher Education in Surakarta, Indonesia," Proceeding The 2nd International Conference On Teacher Training and Education Sebelas Maret University, Indonesia, vol. 2, pp. 630-634, January 2016.

[3] M. Miftahul Khair Nur Ali. "Developing English learning Materials for Young Learners Based on Needs Analysis at MTSN Model Makassar," Journal of UIN Makassar, Indonesia, vol I, pp. 316-330, December 2015.

[4] Peraturan Menteri Pendidikan dan Kebudayaan Republik Indonesia No 31 Tahun 2014 Tentang Kerjasama Penyelenggaraan dan Pengelolaan Pendidikan Oleh Lembaga Pendidikan Asing Dengan Lembaga Pendidikan di Indonesia [Republic of Indonesia Minister of Education and Culture Regulation No. 31 of 2014 concerning Cooperation in the Implementation and Management of Education by Foreign Education Institutions with Educational Institutions in Indonesia]. Jakarta: Kemdikbud

[5] S. Andika Hariyanto. "Needs Analysis in Teaching Learning Process for Developing Teaching Arabic Language Syllabus of Islamic Religion Education of STAIS Sumatera," Journal of STAIN Gajah Putih Takengon, Indonesia, vol. 1, pp. 66-70, November 2015.

[6] S. Beta . "Need Analysis for Identifying ESP Materials for Medical Record Students in APIKES Citra Medika Surakarta," Kajian Linguistik dan Sastra, Indonesia, vol 1, pp. 61-72, June 2016 